\title{
Compound Heterozygote Hemoglobin Lepore-Baltimore Haplotype with $\beta$-Thalassemia
}

\author{
Sujata Dixit ${ }^{1,2} \cdot$ Hemalata Das $^{3} \cdot$ Madhusmita Bal $^{1} \cdot$ Hemant Kumar Khuntia ${ }^{1} \cdot$ Manoranjan Ranjit $^{1}$
}

Received: 6 November 2020 / Accepted: 12 February 2021 / Published online: 10 March 2021

(C) Dr. K C Chaudhuri Foundation 2021

To the Editor: A transfusion dependent 6-y-old boy first born to nonconsanguineous marriage presented with fever $\left(38.2{ }^{\circ} \mathrm{C}\right.$ ), mild jaundice, pallor, hepatosplenomegaly (liver: $12.3 \mathrm{~cm}$, Spleen: $10.5 \mathrm{~cm}$ ) and thalassemia facies was screened for hemoglobinopathy along with his parents at ICMR-RMRC, Bhubaneswar. The patient was anemic [hemoglobin $(\mathrm{Hb}): 7.2 \mathrm{~g} / \mathrm{dL}$ ] showing microcytosis, anisopoikilocytosis, polychromatic red cells with basophilic stippling, and target cells in blood smear. The father's mean corpuscular hemoglobin $(\mathrm{MCH})$ was 21.4 pg and mother's hemoglobin $10.1 \mathrm{~g} / \mathrm{dL}$ along with reduced mean corpuscular volume (MCV) (63.5 fL), but both blood smears showed microcytosis and target cells.

The VARIANT II System (Bio-Rad Laboratories, USA) uncovered presence of $\mathrm{Hb}$ Lepore in father $\{\mathrm{Hb} \mathrm{A} 2: 12.3 \%$ [retention time (RT): $3.52 \mathrm{~min}], \mathrm{Hb} \mathrm{A}_{0}: 75.3 \%$, and $\mathrm{Hb} \mathrm{F}: 4.7 \%$ \} and $\beta$-thalassemia carrier state in mother [Hb A2: $5.4 \%$ (RT: $3.69 \mathrm{~min}$ ), $\mathrm{Hb} \mathrm{A}_{0}: 82.7 \%$, and $\mathrm{Hb} \mathrm{F}: 0.6 \%$. Since the boy was receiving transfusion frequently, deoxyribonucleic acid (DNA) analysis was carried out by passing high-performance liquid chromatography (HPLC) with a presumptive diagnosis of compound heterozygote $\mathrm{Hb}$ Lepore/ $\beta$-thalassemia.

The presence of heterozygous $\mathrm{Hb}$ Lepore in father, $\beta$ thalassemia (IVS I-5 G>C) mutation in mother and compound heterozygote $\mathrm{Hb}$ Lepore/ $\beta$-thalassemia (IVS I-5 G>C) in patient was confirmed by gap polymerase chain reaction (GapPCR) [1] and amplification-refractory mutation system

Manoranjan Ranjit

ranjit62@gmail.com

1 Indian Council of Medical Research (ICMR)-Regional Medical Research Centre, Bhubaneswar 751023, Odisha, India

2 School of Biotechnology, Kalinga Institute of Industrial Technology (KIIT) University, Bhubaneswar, Odisha, India

3 Department of Hematology, Institute of Medical Sciences (IMS) \& SUM Hospital, Siksha 'O' Anusandhan (SOA) University,

Bhubaneswar, Odisha, India
(ARMS)-PCR [2]. $\alpha$ and $\gamma^{\mathrm{G}}$ (Xmn-1 polymorphism) globin in parents and child were normal. Sequencing of $\delta \beta$ fusion gene (777bp mutant fragment) found similarity with Homo sapiens $\mathrm{Hb}$ Lepore-Baltimore (868Leu/ $\beta 84 \mathrm{Thr}$ ) (Accession \# AY695366.1).

$\mathrm{Hb}$ Lepore is an uncommon variant of hemoglobinopathy [3]. Of the three sub-types of $\mathrm{Hb}$ Lepore, $\mathrm{Hb}$ LeporeHollandia $(\delta 22 / \beta 50)$ and $\mathrm{Hb}$ Lepore Boston-Washington $(\delta 87 / \beta 116)$ have been reported in India [3, 4]. This is the first report of $\mathrm{Hb}$ Lepore-Baltimore with $\beta$-thalassemia in a nontribal family of Odisha, India. Our observation highlights that presumptive diagnosis can be made by HPLC but DNA analysis is essential for accurate diagnosis, hence appropriate clinical management and genetic counseling.

\section{Declarations}

Conflict of Interest None.

\section{References}

1. Craig JE, Barnetson RA, Prior J, Raven JL, Thein SL. Rapid detection of deletions causing delta beta thalassemia and hereditary persistence of fetal hemoglobin by enzymatic amplification. Blood. 1994;83(6):1673-82.

2. Old JM. DNA based diagnosis of the hemoglobin disorders. In: Steinberg MH, Forget BG, Higgs DR, Nagel RL, editors. Disorder of Hemoglobin-Genetics, Pathophysiology and Clinical Management. Cambridge: Cambridge University Press; 2001. p. 946-51.

3. Lad H, Yadav M, Mehta P, et al. First observation of Hb Lepore Hollandia in the Baiga tribal family. Indian J Hematol Blood Transfus. 2018;34(3):581-4.

4. Italia K, Sheth J, Sawant P, Nadkarni A, Ghosh K, Colah R. Prenatal diagnosis of HbE-Lepore and $\mathrm{Hb}$ Lepore- $\beta$-thalassemia: the importance of accurate genotyping of the couple at risk. Prenat Diagn. 2012;32(7):703-7.

Publisher's Note Springer Nature remains neutral with regard to jurisdictional claims in published maps and institutional affiliations. 